\title{
Comparative Evaluation of Fodder Yield and Leaf Quality of Some Selected Tree Species
}

\author{
Awotoye O.O.", Ogunbanjo O.R., Jeminiwa S.M., Okanlawon F.B., Oyelami B.A \\ Department of Forestry Technology, Federal College of Forestry, Nigeria
}

Copyright $\bigcirc 2016$ by authors, all rights reserved. Authors agree that this article remains permanently open access under the terms of the Creative Commons Attribution License 4.0 International License

\begin{abstract}
Tropical trees had served a wide range of purpose from supply of timber, fuel wood, pulp and fibre through to fodder, gum, drugs, and dyes. This study considered the fodder yield and leaf quality of three fodder tree species namely: Moringa oleifera, Albizia lebbeck and Gmelina arborea at seedling stage. The experiment was carried out in polythene pot laid out in a completely randomized design with ten replications. Study spanned over a period of twelve weeks. Seedlings were assessed for plant height, number of leaves and stem diameter. Leaf quality parameters assessed were elemental nutrient and proximate composition. Results obtained from the study showed that Moringa oleifera gave the highest mean plant height and mean stem diameter of $30.93 \mathrm{~cm}$ and $3.52 \mathrm{~mm}$ respectively while Gmelina arborea recorded the highest mean number of leaves (8.10) over the study period. Leaf quality analysis revealed that Albizia lebbeck leaves were richest in potassium and copper with values of $5.53 \%$ and $24.23 \mathrm{mg} / \mathrm{g}$ respectively. Moringa oleifera was least in potassium content $(4.55 \%)$. Proximate analysis result indicated that Moringa oleifera had the highest crude protein content of $17.88 \%$ while Albizia lebbeck was best in crude fibre content $(2.00 \%)$. All three tree species recorded no significant difference in dry matter content of $45.08 \%, 45.00 \%$ and $45.63 \%$ respectively. These tree species should be encouraged within the farming system of farmer to aid animal production.
\end{abstract}

Keywords Fodder, Leaf Quality, Nutrient, Proximate

\section{Introduction}

Nutrition had been documented to be one of the most important factors limiting ruminant production, this is because ruminant animals in the smallholder sector depend on natural pastures and crop residues for the greater part of the year. In difficult environmental conditions, where the available grazing is not sufficient to meet the maintenance requirements of animals for part of the year, the contribution from trees and shrubs is significant Sartaj et al, 2014[1] Trees and shrubs are increasingly recognized as important components of animal feeding, especially as suppliers of protein They are readily accepted by livestock and presumably because of their deep-root systems, they continue to produce well into the dry season Von Kauf Mann, 2006[2] In agriculture and forestry, trees and shrubs play an important role within the farming system of the tropical humid regions as they contribute significantly to soil maintenance and livestock production. They provide fodder for animals and replenish soil fertility Whyle, 2001 [3]supplying them with the bulk of their nutritive requirements and complementing their diet with protein, vitamins and minerals Baumer, 2003[4]

This study assessed the nutrient composition and fodder yield of three selected tropical tree species.

\section{Materials and Methods}

\section{Seeds Collection and Planting}

The seeds of Moringa oleifera , $\left(\mathrm{T}_{1}\right)$, Albizia lebbeck $\left(\mathrm{T}_{2}\right)$ and Gmelina aborea $\left(\mathrm{T}_{3}\right)$ were obtained from the seed section of the Forestry Research Institute of Nigeria (FRIN).The seeds were broadcasted into germination boxes and transplanted after two weeks into polythene pots already filled with topsoil. Data collection on plant height, stem diameter and number of leaves of seedlings began two weeks after transplanting.

\section{Chemical Analysis}

The soil used for the study was collected from the Gmelina plantation within the Federal College of Forestry, Ibadan, Oyo State, Nigeria, the area lies between latitude $7^{0} 23^{\mathrm{I}} \mathrm{N}$ and longitude $3^{0} 51^{1} \mathrm{E}$ in the rain forest vegetation of South Western Nigeria with an annual rainfall of about $1300-1500 \mathrm{~mm}$, temperature of about $32^{\circ} \mathrm{C}$ and relative humidity of about $80-85 \%$. FRIN 2014[5] The soil was on analyzed to determine its physiochemical properties. The 
Treatments were carried out in ten replicates of each treatment. Harvesting of plant leaves for proximate analysis occurred 8 weeks after transplanting. The crude protein was calculated using a nitrogen conversion factor of 6.25 Leaf samples were analyzed for total nitrogen, phosphorus, potassium, calcium, magnesium and trace elements $(\mathrm{Cu}$ and $\mathrm{Zn}$ ) in each plant leaf sample AOAC, 1990[6]

Laboratory analysis of experimental soil is as follows: nitrogen $9.06 \%$, phosphorus $1.86 \mathrm{~g} / \mathrm{kg}$, potassium 0.10 $\mathrm{cmol} / \mathrm{kg}$, calcium $0 . .96 \mathrm{cmol} / \mathrm{kg}$, magnesium $0.50 \mathrm{cmol} / \mathrm{kg}$, sodium $0.10 \mathrm{cmol} / \mathrm{kg}$, iron $89.25 \mathrm{mg} / \mathrm{kg}$, zinc $71.56 \mathrm{mg} / \mathrm{kg}$, copper $41.24 \mathrm{mg} / \mathrm{kg}$,

\section{Statistical Analysis}

The design of the research was complete randomized design in ten replicates of each treatment. All data obtained from this experiment was statistically analyzed by using the ASSITAT software. The statistical significance of differences among the mean values was determined by DMRT test at $5 \%$ probability level.

\section{Results and Discussion}

Seedlings of Moringa oleifera, Albizia lebbeck and Gmelina aborea were assessed for plant height, number of leaves and stem diameter. Result obtained indicated that Moringa oleifera performed best in plant height and stem diameter with a mean value of $30.93 \mathrm{~cm}$ and $3.52 \mathrm{~mm}$ respectively. This is in line with the findings of Att-krah et al 1996 [7]who established that out of some indigenous fodder trees and shrubs, Moringa oleifera can be considered as one of the fast growing species in the tropics.
Table 1. Results of Seedlings Growth Parameters

\begin{tabular}{|c|c|c|c|}
\hline Sample & $\begin{array}{c}\text { Height } \\
(\mathbf{c m})\end{array}$ & $\begin{array}{c}\text { Stem diameter } \\
(\mathbf{m m})\end{array}$ & $\begin{array}{c}\text { Number of } \\
\text { Leaves }\end{array}$ \\
\hline $\mathrm{T}_{1}$ & $30.93 \mathrm{a}$ & $3.52 \mathrm{a}$ & $6.60 \mathrm{~b}$ \\
\hline $\mathrm{T}_{2}$ & $7.81 \mathrm{~b}$ & $2.04 \mathrm{bc}$ & $5.30 \mathrm{~b}$ \\
\hline $\mathrm{T}_{3}$ & $8.83 \mathrm{~b}$ & $1.66 \mathrm{c}$ & $8.10 \mathrm{a}$ \\
\hline $\begin{array}{c}\text { Grand } \\
\text { mean }\end{array}$ & 15.86 & 2.40 & 6.66 \\
\hline Sig & $57.79^{*}$ & $6.65^{*}$ & $3.54^{*}$ \\
\hline $\mathrm{CV}(\%)$ & 16.35 & 47.97 & 21.19 \\
\hline
\end{tabular}

NOTE; Means with the same alphabet are not significantly different from each other.

For number of leaves, however, result indicated that Gmelina aborea seedlings produced the highest number of leaves with a mean value of 8.10 , this was followed by Moringa oleifera with a value of 6.60 and the least value of 5.30 was produced by Albizia lebbeck. This contradicts the findings of Att-krah et al 1996 [7]who reported that out of all species assessed, Gliricidia sepium had the highest yield production.

Wide variation was observed for Nitrogen, which is very essential for plant growth and serves as a source of supplementary energy for animal feeding, Moringa oleifera recorded the highest mean value of $4.64 \%$ while the lowest value was recorded for Albizia lebbeck with a mean value of $1.08 \%$. Moringa oleifera leaves are regarded as a valuable source of protein for ruminants and are used in small holder rabbit farming in several African countries. Carew 1982 [8] on the other hand, from his findings reported that Gliricidia sepium had a higher Nitrogen content with values ranging between $3.2 \%$ and $4.21 \%$.

Table 2. Nutrient Composition Results of selected tree species

\begin{tabular}{|c|c|c|c|c|c|c|}
\hline Sample & $\begin{array}{c}\text { Biomass } \\
\text { (g/pot) }\end{array}$ & Nitrogen (\%) & $\begin{array}{c}\text { Phosphorus } \\
\mathbf{( \% )}\end{array}$ & Potassium (\%) & $\begin{array}{c}\text { Copper } \\
\text { (mg/g) }\end{array}$ & Zinc (mg/g) \\
\hline $\mathrm{T}_{1}$ & $5.27 \mathrm{a}$ & $4.64 \mathrm{a}$ & $1.75 \mathrm{ab}$ & $4.55 \mathrm{c}$ & $23.63 \mathrm{~b}$ & $65.11 \mathrm{c}$ \\
\hline $\mathrm{T}_{2}$ & $5.33 \mathrm{a}$ & $1.08 \mathrm{~b}$ & $1.16 \mathrm{~b}$ & $5.53 \mathrm{a}$ & $24.23 \mathrm{a}$ & $106.93 \mathrm{~b}$ \\
\hline $\mathrm{T}_{3}$ & $1.33 \mathrm{~b}$ & $1.56 \mathrm{~b}$ & $0.92 \mathrm{c}$ & $4.93 \mathrm{~b}$ & $9.27 \mathrm{c}$ & $322.71 \mathrm{a}$ \\
\hline Grand Mean & 3.98 & 2.43 & 1.27 & 5.00 & 19.04 & 164.92 \\
\hline Sig & $2.32^{*}$ & $24.26^{*}$ & $12.76^{*}$ & $2.48^{*}$ & $3.18^{*}$ & $136.13^{*}$ \\
\hline CV (\%) & 104.35 & 24.42 & 3.02 & 0.90 & 0.19 & 3681.43 \\
\hline
\end{tabular}

NOTE; Means with the same alphabet are not significantly different from each other.

Table 3. Proximate Composition Results of Tree Species

\begin{tabular}{|c|c|c|c|c|c|c|}
\hline Sample & Dry Matter (\%) & Ether Extract (\%) & Ash (\%) & Crude Protein (\%) & Crude Fibre (\%) & CHO (\%) \\
\hline $\mathrm{T}_{1}$ & $45.08 \mathrm{a}$ & $25.00 \mathrm{a}$ & $7.84 \mathrm{a}$ & $17.88 \mathrm{a}$ & $1.50 \mathrm{a}$ & $22.54 \mathrm{~b}$ \\
\hline $\mathrm{T}_{2}$ & $45.00 \mathrm{a}$ & $20.00 \mathrm{~b}$ & $7.00 \mathrm{a}$ & $17.44 \mathrm{a}$ & $2.00 \mathrm{a}$ & $23.36 \mathrm{~b}$ \\
\hline $\mathrm{T}_{3}$ & $45.63 \mathrm{a}$ & $20.00 \mathrm{~b}$ & $5.50 \mathrm{a}$ & $14.33 \mathrm{~b}$ & $1.50 \mathrm{a}$ & $27.99 \mathrm{a}$ \\
\hline Grand Mean & 45.24 & 21.67 & 6.78 & 16.55 & 1.66 & 24.63 \\
\hline Sig & $0.23^{\text {ns }}$ & $8.83 *$ & $2.09^{\text {ns }}$ & $8.281^{*}$ & $0.26^{\text {ns }}$ & $9.28^{*}$ \\
\hline CV (\%) & 35.614 & 109.98 & 36.91 & 26.04 & 54.18 & 30.63 \\
\hline
\end{tabular}

NOTE; Means with the same alphabet are not significantly different from each other. 
For copper and pottassium, Albizia lebbeck was recorded to have the highest mean values of $24.23 \%$ and $5.53 \%$ respectively. Moringa oleifera recorded the highest value for phosphorus, followed by Albizia lebbeck $1.16 \%$ while Gmelina arborea recorded the lowest value of $0.92 \%$.

From the above table, it can be deduced that Moringa oleifera had the highest content value of $25.00 \%$ for Ether extract, this was closely followed by the duo of Albizia lebbeck and Gmelina arborea carrying the same content value of $20.00 \%$.

For crude protein, Moringa oleifera recorded the highest content value of $17.88 \%$ indicating Moringa oleifera leaves as good protein supplement while Gmelina arborea recorded the lowest $14.33 \%$ This supports the findings of Onwuka 1980 [9] who reported that the main features of browse plants are their high crude protein and mineral content, he added that average trees and shrubs are richer in crude protein and lower in crude fibre and ash than tropical grasses. Moringa oleifera leaf meal replaced $20 \%$ of soybean meal protein and rabbit performance was significantly better than those allowed by control diet, Ayodele et al, 2014 [10] Amanulla et al, 2006 [11] however reported Albizia lebbeck to be very rich in crude protein with a mean value of $20 \%$.

Albizia lebbeck had the highest content of crude fibre $(2.00 \%)$ while Moringa oleifera and Gmelina arborea carried the same value of $1.50 \%$, indicating these are potentially more digestible and better sources of feed to livestock. Fodders containing high level of fibre are more suitable for cattle, sheep and goats than for non ruminants like pigs and chickens Edwards, 2008 [12]. Carbohydrate content was highest in Gmelina arborea with a value of $27.99 \%$ and lowest in Moringa oleifera $22.54 \%$. No significant difference was however recorded in all the three tree species in terms of dry matter content, with Moringa oleifera having a mean value of $45.08 \%$, Albizia lebbeck $45.00 \%$ and Gmelina arborea $45.63 \%$.

\section{Conclusions and Recommendation}

Fodder trees and shrubs have always played a significant role in feeding livestock. Trees and shrubs are usually recognized as important component of animal feeding, most especially as protein suppliers usually in harsh environmental conditions, where the available grazing is not generally to meet the maintenance requirement of animals .Being perennials trees are more able to withstand prolonged periods of water inadequacy than grasses. Considering the large amount of nutrients available in the selected tree species, more emphasis should be placed on the cultivation and raising of such seedlings to enhance growth and development in animal and subsequently human beings.
Farmers should as well be encouraged to raise fast growing trees as well as those with high production of leaves which are palatable and as well aid livestock's digestivity.

\section{REFERENCES}

[1] Sartaj K., Khurshaid A., Khisrao K, Asad S., Sayed Z.S., Zahoor A., Hafiz M.I., Sajjad K., and Safirullah (2014): Nutritional Evaluation of Some Top Fodder Tree Leaves and Shrubs of District Dir (Lower), Pakistan as a quality livestock feed. International Journal of Current Microbiology and Applied Science Vol3 (5):941-947

[2] Von Kaufmann M .(2006): An Introduction to research in Nigeria's sub humid zone. Proceedings of the second ILCA/NAPRI symposium held in Kaduna Nigeria, 29th Oct -2nd Nov 1994.ILCA, Addis Ababa Ethiopia.pp18

[3] Whyle,R.D (2001): The use and misuse of shrubs and trees as fodder. Commonwealth Agricultural Bureau, publication No. 10 .

[4] Baumer ,M. (2003) : Notes on trees and shrubs in Arid and Semi-Arid regions. EMASA, Phase U . FAO, Rome Italy. No.13. pp 431-524.

[5] Forestry Research Institute Of Nigeria Annual Meteorological Report, (2014).

[6] AOAC. (1990) : Official methods of analysis, Association of Official Analytical Chemists, Washington, D.C., USA. 15 th Edition, pp.807-928.

[7] Atta-krah,A.N., Sumberg J.E and Reynolds (1996): Leguminous fodder trees in farming system, an overview of AOAC. AOAC. (1990) : Official methods of analysis, Association of Official Analytical Chemists, WashingD.C., USA. 15 th Edition, pp.807-928.research at humid zone programme of ILLA in South Western Nigeria.In potentials of forage legumes in farming system of Sub Saharan Africa-Haqued.,Jutzi, S.and Weate,P.J.(eds) 113-121.

[8] Carew A.R (1982): Uses of Gliricidia sepium as a forage feed in small ruminant production -a progress report ILCA, Ibadan. pp 117-234.

[9] Onwuka C.F (1980): The chemical composition and "In-vitro" organic matter digestibility of some browse plants in Nigeria .M.Sc Thesis. University of Ibadan, Nigeria 70pp.

[10] Ayodele, A.E; Adeola, J.R, Mayowa, A.T (2014). Reproductive performance of rabbit does fed graded levels of Moringa oleifera leaf meal based diet. Int. J. Sci.,3(3):50-531

[11] Amanullah, M,M., Somasundaram, E.; Alagesan, A.; Vaiyapuri,K.; Paazhanivelan, S.;Sathyamoorthi,K.,(2006): Evaluation of some tree species for leaf fodder in Tamil Nadu.Res.J.Agric.Biol.Sci.,2(6);552-553.

[12] Edwards, L.C. (2008): Some notes on the food of goats in a semi-arid area. The East African Agricultural Journal 13(4). 